\title{
Landslide inventory of the Crasna catchment, Moldavian Plateau, Romania
}

\author{
Alina Bejenaru, Mihai Niculiţă \\ Department of Geography, Geography and Geology Faculty \\ Alexandru Ioan Cuza University of Iaşi \\ Iaşi, Romania \\ bejenarualina96@yahoo.com, mihai.niculita@uaic.ro
}

\begin{abstract}
Spatial landslide inventories are fundamental elements for landslide spatial susceptibility and landslide hazard modelling. These are digital spatial databases which indicate the spatial presence and the spatial extent of the landslide events or complexes. In the present study we describe the creation and the statistical validation of a landslide inventory for the Crasna catchment, left tributary of the Bârlad river, Moldavian Plateau. In this catchment, with an area of $185.2 \mathrm{~km}^{2}, 1619$ polygons were delineated, representing landslides which have a clear and distinct morphological signature on high resolution DEMs. Beside the DEMs, high resolution imagery from the Google Earth and Bing Maps archives and old and recent aerial images were used to supplement the morphological information. The obtained inventory is a geomorphological one and a historical one because it contains all the landslides, relict, old and recent, that are recognizable in the actual geomorphological context. The criteria for landslide delineation was mainly the morphological one, respectively the presence of any of the following landslide elements: principal and secondary scarps, landslide body with rough topography, bedding traces, landslide foot, tip, toe and flanks. Beside the landslide delineation, the landslide inventory contains data about the typology of the landslide (using the Cruden, Varnes \& Hungr classifications), inferred from the morphology, the landslide age inferred from the geomorphological and topological information of the remote sensing data. The validity of the inventory was tested and argued using the Malamud et al., 2004 landslide area distribution frequency. This shows that the magnitudes of the landslides from the Lohan catchment are distributed in a similar way as landslide magnitude is distributed in other areas of the globe.
\end{abstract}

Keywords- landslide inventory; Crasna catchment; Moldavian Plateau

\section{INTRODUCTION}

Landslides represent a common geomorphologic hazard in the Moldavian Plateau and in the Crasna catchment, landslide being an important geomorphologic process that shapes the landforms. While the area is characterized mainly by rural settlements, many of these settlements are located on hillslopes, where there is protection against the winter winds and floods, but where relict and old landslides are present. Beside the settlements, vulnerable infrastructure is situated in the Lohan catchment: the European 581 road from Huşi to Bârlad and the Huşi-Bârlad railway. While the European road is situated along the floodplain and at the base of the right hillslope, and is not so vulnerable to landslides, the railway runs through the right hillslope of the Lohan valley, being very vulnerable to landslides.

Landslides inventories are the main sources for landslide analysis [1], either for landslide analysis or landslide hazards. Knowing the repartition and the main causes of landslides, has an important role in the risk assessment which is needed for spatial planning in the Crasna catchment.

\section{STUDY AREA}

The Crasna catchment is located in the eastern part of the Central Moldavian Plateau, North-Eastern Romania (Fig. 1).

\section{A. Geology}

The monoclinic strata which has a NW to SE dip and various strikes is of Middle to Upper Miocene age [2]. The majority of the study area has Upper Sarmatian (Kersonian) bedrock, only the upper part of the hillslopes which have altitude beyond $350 \mathrm{~m}$ a.s.l., in the central, north-western and eastern part of the catchment being developed on Meotian rocks. The Kersonian rocks have in the northern and the middle part of the catchment a sandy deltaic facies, while in the lower part of the catchment have a sandy brackish facies. The Meotian rocks have an andesitic cineritic tuff with cineritic sands intercalation base, which is covered by sands, clays and silts. The hillslopes which have at the base and median part the Kersonian sands and the cineritic tuff at the upper part have altitude range over $100 \mathrm{~m}$, and develop a specific morphology, with an upper steep escarpment, where the bedding is visible, and a medium and lower par which is not so steep and is covered by thick landslide deposits and hillslope deposits. Usually these hillslopes are developed as NE to SW alignments, which are not fragmented by valleys.

\section{B. Landforms}

The channel network has a pronounced asymmetry, the tributaries from the right side (Cetăţuia, Gănești, Blăneşti, 


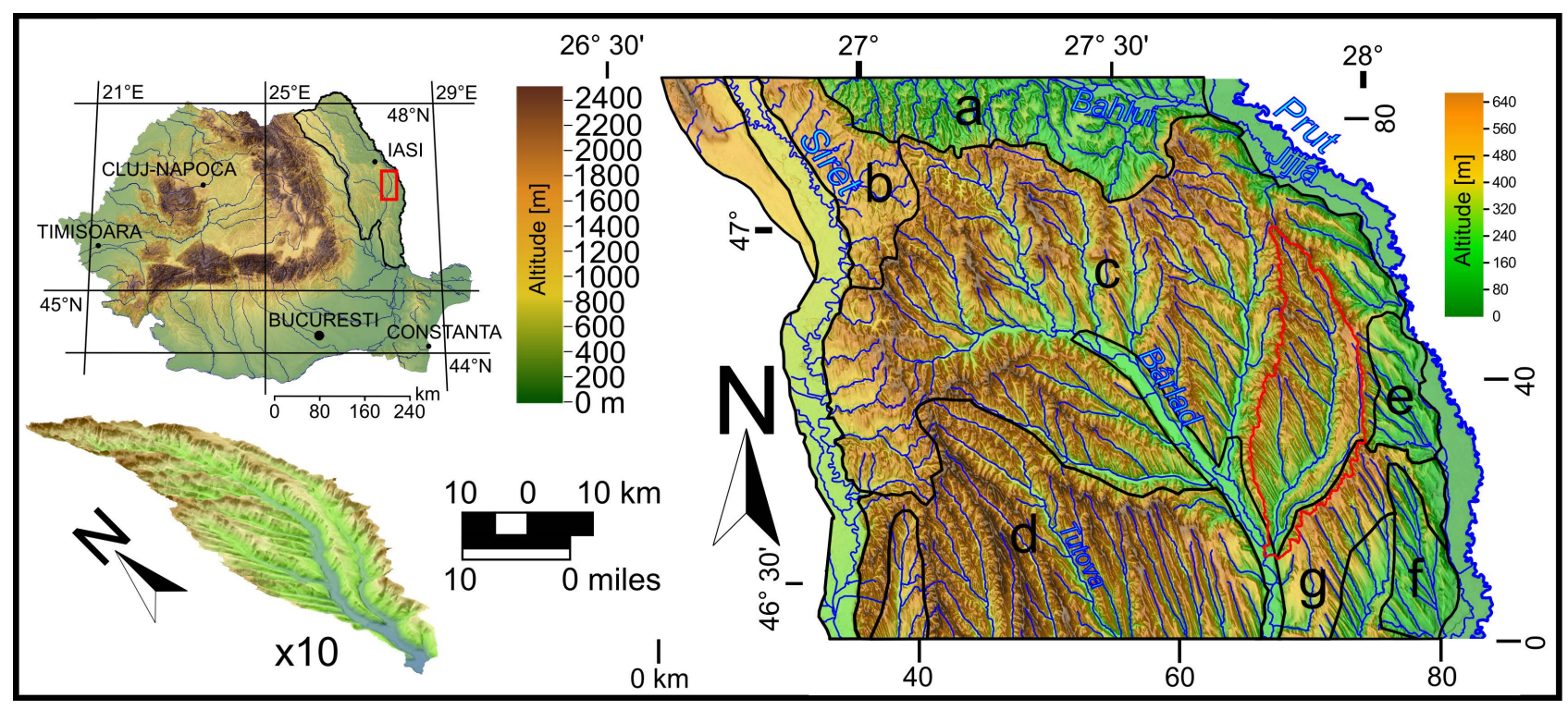

Fig. 1. The geographic position of the Crasna catchment in Romania and in the Moldavian Plateau: a) Jijia Hills, b) Suceava Plateau, c) Central Moldavian Plateau, d) Tutovei Hills, e) Huşi Depression, f) Sărata Depression, g) Fălciu Hills; in the lower left part a tridimensional view of the study area.

Bălţaţi, Burghina - Fig. 3a) being much longer than those form the left side.

This situation happens also for the Lohan catchment, the main tributary of Crasna. This predictive patterns is due to the monoclinic geological structure, which has a NW to SE dip, the main channel network with a NE to SE flow direction suffering a homoclinal shifting toward SE (Fig. 3a).

The floodplains are generally flat, from 200 to $1000 \mathrm{~m}$ wide, and have narrow and not so deep channels (1-2 m). The landforms also present a predictive patterns of asymmetry: hills have usually the NW hillslope steeper and shorter, than the SE hillslope which is gentle and long.

The altitude ranges between $82 \mathrm{~m}$ a.s.l. in south, at the confluence with Bârlad river, to $424 \mathrm{~m}$ a.s.l. in NW. The mean altitude is $221 \mathrm{~m}$ a.s.l., with a standard deviation of $63 \mathrm{~m}$. The altitude range between local valleys and ridges is under $100 \mathrm{~m}$, only along Lohan valley and in the middle sector of Crasna valley this range going up to $150 \mathrm{~m}$, because on the left side of these valleys massive cuesta escarpments appear.

\section{MAterials AND METHODS}

The main source for landslide delineation was a LiDAR DEM with $0.5 \mathrm{~m}$ resolution. Geomorphometric variables (shading, slope, curvatures, slope edge detection) were derived from this DEM and used in the visualization were the landslide delineation was performed. The delineation was performed in Google Earth, in 3D mode, in order to correctly assess the geomorphological situation. Beside the geomorphometric data, Google Earth imagery archive was used to evaluate the landslide elements. Various image acquisition times during the day (morning time images, which have good shades are better than midday time images when the shades are minimal) or during the year (winter, spring and autumn times images, when vegetation is not yet developed and snow might occur in shaded areas are better than summer time, when the vegetation is fully developed) can supplement the morphometric data, in order to assess the presence of escarpments and the roughness of the landslide body. Topographic profiles were also used in order to understand the landslide flow mechanism.

A landslide polygon was delineated (Fig. 2) when at least three of the following landslide elements [3, 4] were found:

- $\quad$ Landslide crown or main scarp;

- Landslide body with secondary scarps and roughness different from the non-slided hillslope;

- $\quad$ Landslide flanks and landslide toe and tip.

For every landslide polygon, after the delineation the following attributes were assigned:

- Landslide type, translational slide, rotational slide, earth flow, spreads and complex;

- $\quad$ Landslide age, relict, old and recent [5].

\section{RESULTS}

In total 1619 landslide polygons were delineated (Fig. 3b). The majority of the landslides are relict or old complex landslides, with translational/rotational reactivations on the scarp and on the landslide body. These complex landslides, beside the complex typology of the movement are not the result of a single event, but are the result of multiple events, which usually generated the extension of the landslide processes along the entire hillslopes, bot laterally and along the slope [2, 6]. These complex landslides can be characterized either by or by big dep seated events, followed by scarp reactivations.

The majority of the individual landslides (which are not reactivations) are old or recent age translational landslides. Rotational and earth flows having old or recent age represent under $20 \%$ of individual landslides.

The spatial distribution of the landslides, revealed by the landslide index (Fig. 3c) [7] show a spatial clustering of the complex and individual landslides along the steep cuesta escarpments along the main rivers. 


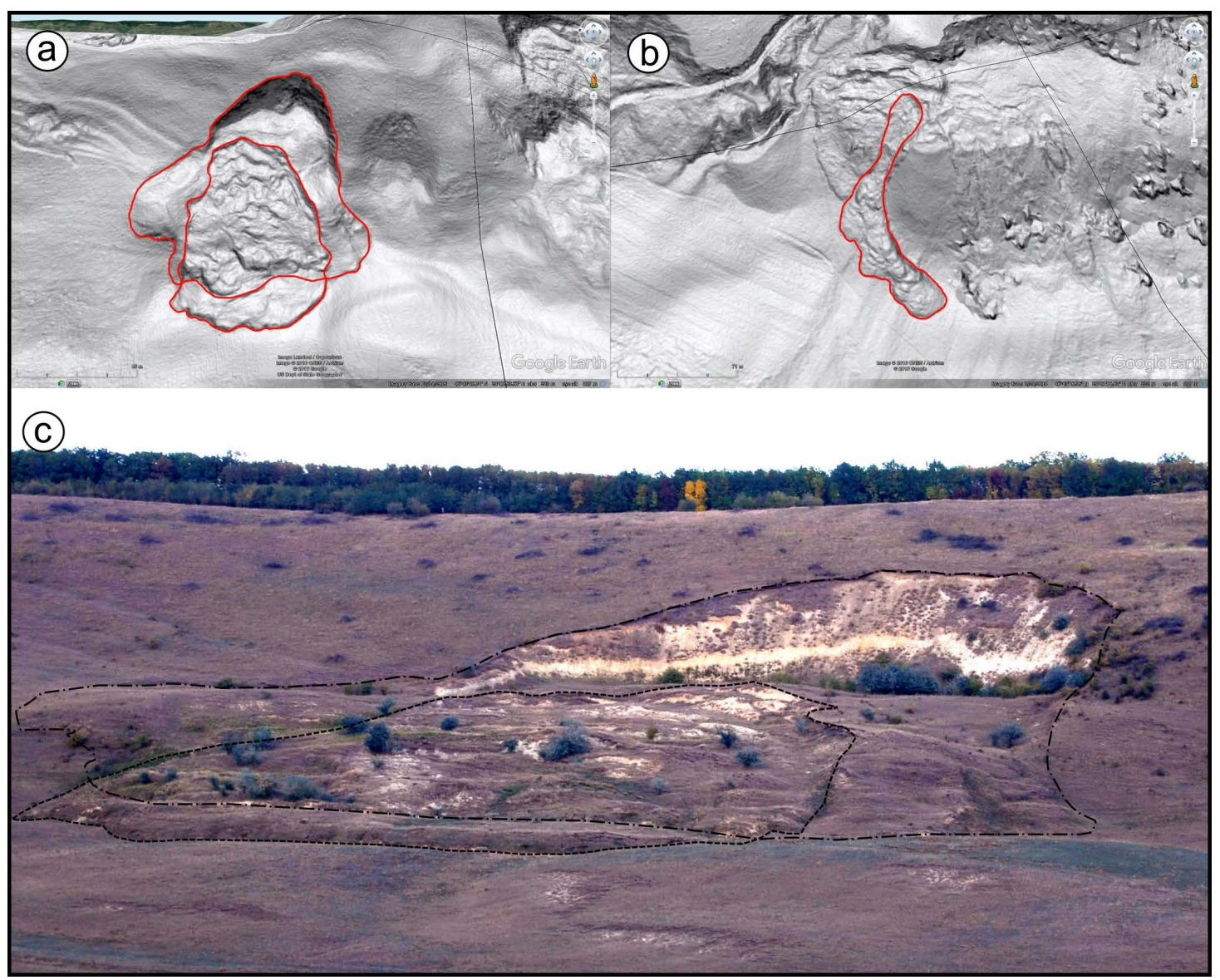

Fig. 2. Examples of delineated landslides: a - shaded view of a rotational landslide affected by a translational landslide, b - shaded view of an earth flow, c - field situation with the landslides from a.

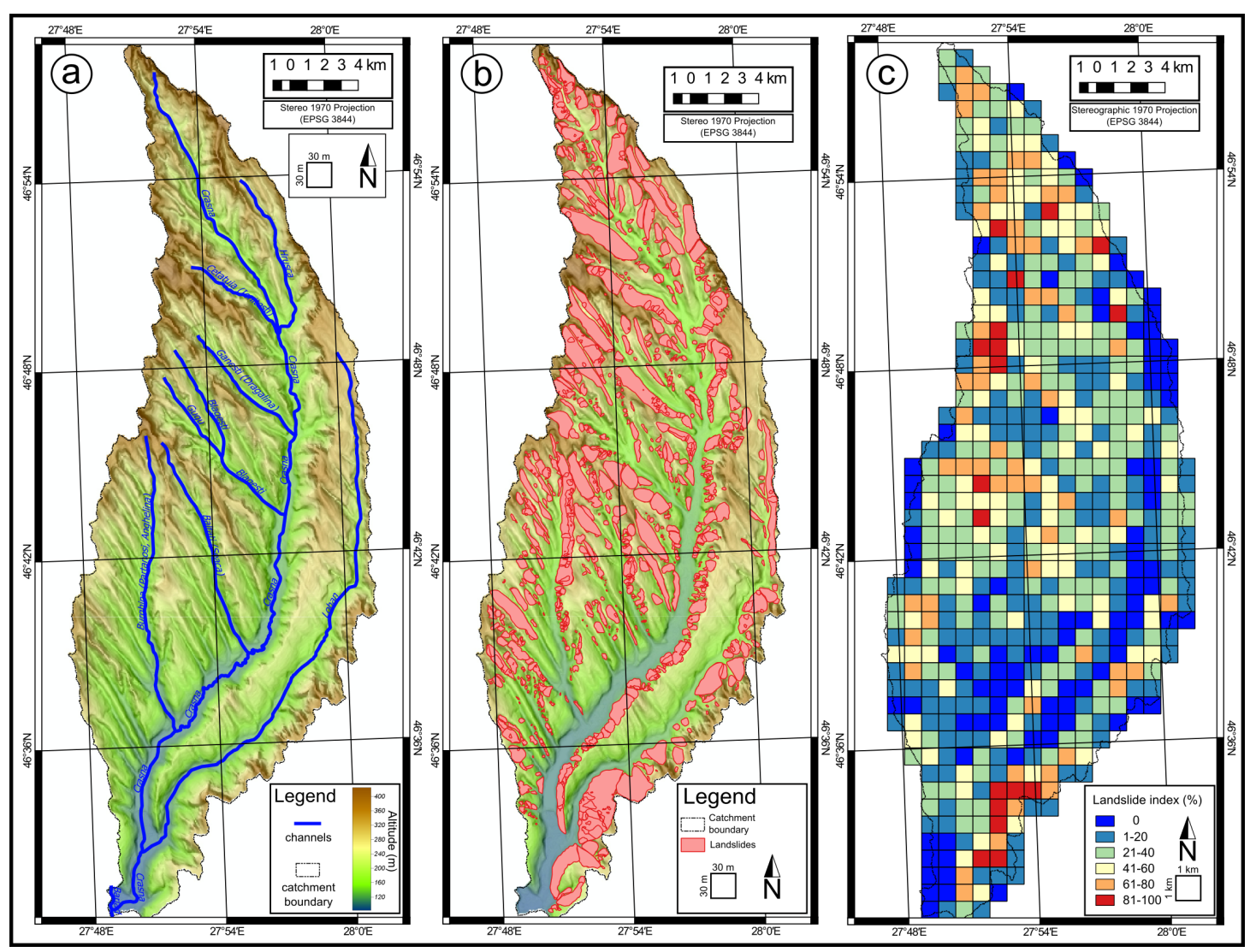

Fig. 3. Hipsometry (a), landslide inventory (b) and landslide index (c) of Crasna catchment. 
The biggest clusters of landslides are located where the amplitude of the altitude is highest along these steep slopes: the left hillslope in the lower part of Lohan catchment and the upper part of Găgești catchment, showing that the fluvial incision controlled the landsliding.

Gentle cuesta dip slopes are affected by landslides, only where the drainage network is incised. The landslides from these areas are also complex landslides, fact that we believe that argue a quick incision.

In the upper part of the Crasna valley, because of the symmetry of the valley profile, the landslide density increase on both hillslopes, which is believe is also generated by the river incision.

\section{Discussions}

To check the validity and the completeness of the inventory we have analyzed the frequency distribution of the landslide area (Fig. 4) [8, 9, 10]. Although the distribution has an inverse gamma shape, it is different than other historical landslide inventories, by the slope of the tail, mainly because the use of LiDAR data allowed us to delineate every complex landslide. These complex landslide have big surface, which spans two orders of magnitude. In this part of the curve, the landslide magnitude is overestimated. In the same time in the smaller landslides part of the curve, compared with previous results in the Moldavian Plateau [2,5] the inventory is complete. This result show that when LiDAR data is used in conjunction with high resolution aerial imagery for landslide delineation, a higher number of landslide events can be delineated.

\section{CONCLUSIONS}

The landslide inventory of the Crasna catchment represent a first crucial step toward landslide hazard and risk assessment. The analysis of the typology and spatial distribution of landslides form the inventory show the control of landforms and river incision on landslide development. The area distribution analysis show that while the LiDAR data is useful for complete characterization of small and mean magnitude individual landslides, the complex landslides are a feature which characterize the Moldavian Plateau, which need further study in order to assess the characteristic size of the biggest magnitudes.

\section{ACKNOWLEDGMENT}

We are grateful to Prut-Bârlad Water Administration who provided us with the LIDAR data. We have used the computational facilities given by the infrastructure provided through the POSCCE-O 2.2.1, SMIS-CSNR 13984-901, No. 257/28.09.2010 Project, CERNESIM (L4).

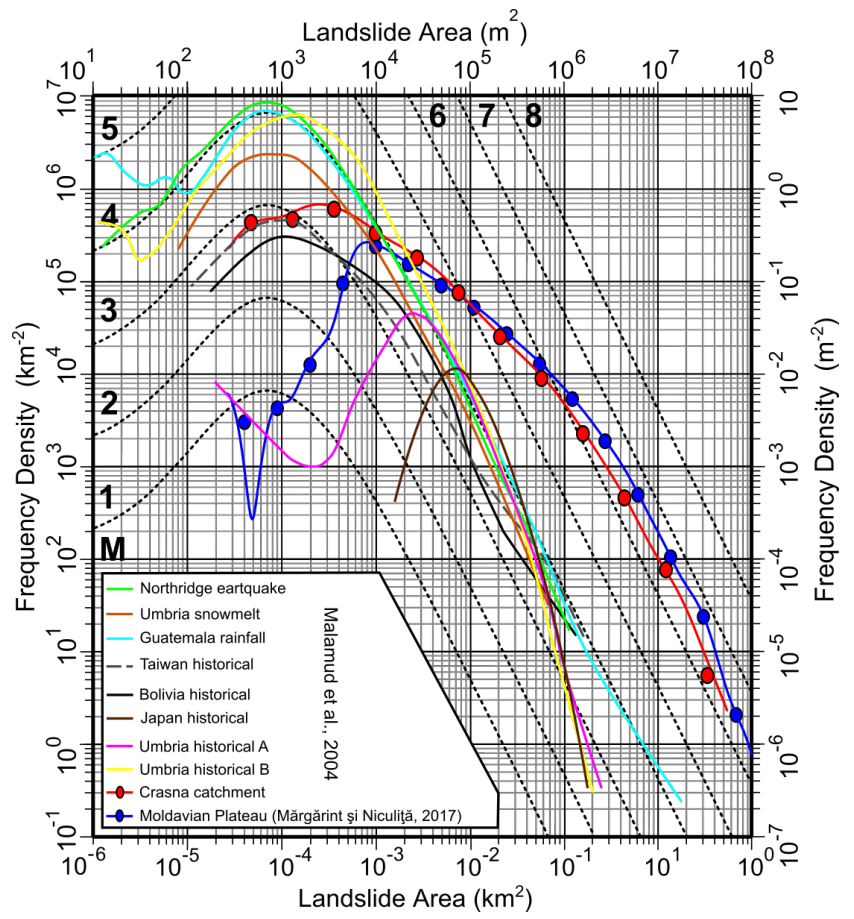

Fig. 4. The landslide frequency density curve for the Crasna catchment, for the Moldavian Plateau [2], and for other areas in the world [8, 9]

\section{REFERENCES}

[1] F. Guzzetti, A.C. Mondini, M. Cardinali, F. Fiorucci, M. Santangelo, and K.-T. Chang, "Landslide inventory maps: New tools for an old problem,” Earth-Science Reviews, vol. 112, pp. 4266, 2012.

[2] M.C. Mărgărint and M. Niculiță "Landslide type and pattern in Moldavian Plateau, NE Romania,” in M. Rădoane and A. Vespremeanu (eds.) Landform Dynamics and Evolution in Romania, Springer, 2017, pp. 271-304.

[3] D.M. Cruden and D.J. Varnes, "Landslide types and processes" in Landslides investigation and mitigation, Transportation Research Borad, US National Council, Special Report 247, A.K. Turner and R.L. Schuster, Eds. Washington DC: 1996, pp. 36-75.

[4] O. Hungr, S. Leroueil, and L. Picarelli, "The Varnes classification of landslide types, an update”, Landslides, vol. 11, no. 2, pp. 167194, 2014.

[5] M. Niculiţă, M.C. Mărgărint, and M. Santangelo, “Archaeological evidence for Holocene landslide activity in the Eastern Carpathian lowland,” Quaternary International, vol. 415, pp. 175-189, 2016.

[6] M. Niculiţă and M.C. Mărgărint, "Landslide inventory for the Moldavian Plateau," in Proceedings of the international conference Analysis and management of changing risks for Natural Hazards, 18-19 Nov. 2014, Padua, Italy, http://www.changesitn.eu/Portals/0/Content/2014/Final\% 20conference/ abstracts/AP3_Abstract_Niculita.pdf.

[7] A. Trigila, C. Iadanza, and D. Spizzichino, "Quality assessment of the Italian Landslide Inventory using GIS processing” Landslides, vol. 7, pp. 455-470, 2010.

[8] B.D. Malamud, D.L. Turcotte, F. Guzzetti, and P. Reichenbach, "Landslide, earthquakes, and erosion," Earth Planet Sci Lett, vol. 229, pp. 45-59, 2004.

[9] B.D. Malamud, D.L. Turcotte, F. Guzzetti, and P. Reichenbach, "Landslide inventories and their statistical properties," Earth Surf Proc Landf, vol. 29, pp. 687-711, 2004.

[10] M. Rossi, M. Cardinali, F. Fiorucci, I. Marchesini, A.C. Mondini, M. Santangelo, S. Gosh, D.E.L. Riguer, T. Lahousse, and K. Chang, F. Guzzetti "A tool for the estimation of the distribution of landslide area in R,” Geophysical Research Abstracts, Vol. 14, EGU2012-9438-1, 2012. 